\title{
A saint, an abbot, his documents and her property: power, reform and landholding in the monastery of Homblières under Abbot Berner (949-82)
}

\section{Fraser McNair}

To cite this article: Fraser McNair (2015) A saint, an abbot, his documents and her property: power, reform and landholding in the monastery of Homblières under Abbot Berner (949-82), Journal of Medieval History, 41:2, 155-168, DOI: 10.1080/03044181.2015.1026380

To link to this article: https://doi.org/10.1080/03044181.2015.1026380

\section{(c) 2015 The Author(s). Published by Taylor \& Francis.}

\section{Published online: 19 Mar 2015.}

Submit your article to this journal ¿

Џ Article views: 806

Q View related articles $\sqsubset$

\section{View Crossmark data ¿}




\title{
A saint, an abbot, his documents and her property: power, reform and landholding in the monastery of Homblières under Abbot Berner (949-82)
}

\author{
Fraser McNair* \\ Pembroke College, Cambridge, CB2 1RF, United Kingdom \\ (Received 26 February 2014; final version received 17 July 2014)
}

\begin{abstract}
The monastery of Homblières, after 949, when it was turned from a community of nuns into a reformed Benedictine monastery under the rule of Abbot Berner, left a surprisingly large amount of tenth-century written material, producing both a Vita and a Translatio of Homblières' patron saint Hunegund, as well as a large collection of charters. These documents allow us crucial insights into how a small monastery managed its possessions and its connections to patrons. This trail permits a closer view of strategies of landholding than can be had with many West Frankish monasteries. This article argues that the community at Homblières acted over several decades to consolidate its lands in specific locations. By producing such extensive documentation of his activities, Berner both solicited further donations for his monastery and protected its existing patrimony from potential threats.
\end{abstract}

Keywords: Homblières; Abbot Berner; St Hunegund; charters; monastic reform

The little monastery of Homblières, today mostly ruined, lies a few kilometres away from the town of Saint-Quentin in Vermandois in north-eastern France. Founded in the mid-seventh century by a local woman named Hunegund, later one of the monastery's patron saints, nothing is known for certain of the abbey's history until the $940 \mathrm{~s} .{ }^{1}$ In the mid-940s, Archbishop Artald of Rheims imposed a new abbess, Bertha, on the nuns; shortly afterwards, in 949, the nuns were replaced by monks under the rule of Abbot Berner. Homblières was never a great monastery, but it is remarkable in tenth-century Vermandois: unlike most of its neighbours in the north-east of the West Frankish kingdom, Homblières left a relatively substantial corpus of documentary material. ${ }^{2}$ This corpus throws light on how a small monastery might be carefully managed to consolidate its patrimony and protect its landholdings from potential challenges. Given the lack of comparable tenth-century collections from the eastern portions of the West Frankish kingdom - which, unlike other places (most

\footnotetext{
*Email: fam38@cam.ac.uk

${ }^{1}$ The following abbreviations are used in this article: MGH: Monumenta Germaniae Historica; SS: Scriptores in folio.

Thedore Evergates, introduction to The Cartulary and Charters of Notre-Dame of Homblières, ed. Theodore Evergates, with Giles Constable, based on work by William Mendel Newman (Cambridge, MA: Medieval Academy of America, 1990), 1-2, for an introduction to the monastery.

${ }^{2}$ Evergates, ed., Cartulary of Homblières, 20.
} 
notably Lotharingia and the Loire valley), has a limited base of documentary material - this evidence deserves a closer study by historians than it has yet received. ${ }^{3}$

Recent years have seen numerous developments in the historiography of tenth-century monasticism, many of them focusing around the ideas and practices of monastic reform which began to develop at this time. ${ }^{4}$ Modern historians have highlighted how the tenth century never saw a single reform movement, but rather a variety of impetuses for reform emerging from different centres, influencing, complementing and potentially competing with one another. ${ }^{5}$ The neat, almost institutional, reform movement presented in Hallinger's monumental tomes on Gorze-Kluny has now been exchanged in the historiographical imagination with a kaleidoscope of 'reformist' interest groups. ${ }^{6}$

There has also been a certain tendency within studies of monasticism to use local case studies to point to wider trends within monasticism. This was the approach, for instance, of Helvétius' work on Hainaut, of Patzold's work on conflict within abbeys within the Ottonian Reich, of Nightingale's studies of reforming monasteries in Lotharingia, and of Vanderputten's work on the monasteries of Flanders. ${ }^{7}$ This article does indeed look at how the material from Homblières connects to wider trends within monasticism. However, owing to the nearcomplete absence of information about the state of Homblières before the reforms of the mid940 s, it can only be used in a limited way as a case study for the effects of reform. Instead, the Homblières material can be used to throw light on how Abbot Berner and his community managed their landholdings and solicited patronage. This is particularly significant because Homblières was a small and poor monastery. Most houses with a tenth-century documentary trail of this size tend to be major houses, such as Gorze or Saint-Aubin of Angers. However, the charters and hagiographies of tenth-century Homblières can be used to show the way in which strategies of landholding and patronage management could be translated onto a smaller scale.

Attention must also be paid to what made Homblières different. Aside from its material poverty, Homblières was unusual among many West Frankish monasteries in having no single chief patron. A more typical pattern among monasteries reformed in this period was to have one patron, whose alliance with a potential reformer was one of the factors which allowed a faction favouring change to come into power in a given institution. Hence, in the closest West

\footnotetext{
${ }^{3}$ See in the first instance Pierre Héliot, 'L'abbaye de Homblières et la châsse de sainte Hunégonde aux Xe et XIe siècles', Bibliothèque de l'École des Chartes 119 (1961): 226-33; Joseph Van der Straeten, 'Sainte Hunegonde d'Homblières, son culte et sa vie rhythmique', Analecta Bollandiana 72 (1954): 39-74; see also Robert Fossier, 'Le Vermandois au Xe siècle', in Media in Francia: recueil de mélanges offert à Karl Ferdinand Werner (Maulévrier: Hérault-Éditions, 1989), 177-86, who uses the Homblières material to address a different topic.

${ }^{4}$ Raymund Kottje, 'Einleitung: monastische Reform oder Reformen?', in Monastische Reformen im 9. und 10. Jahrhundert, eds. Raymund Kottje and Helmut Maurer (Sigmaringen: Jan Thorbecke Verlag, 1989), 913; Isabelle Rosé, 'Les moines et leur vie communautaire du IXe au XIIe siècle: tour d'horizon historiographique', in Ecclesia in medio nationis: Reflections on the Study of Monasticism in the Central Middle Ages, eds. Steven Vanderputten and Brigitte Meijns (Leuven: Leuven University Press, 2011), 11-45; Steven Vanderputten, Monastic Reform as Process: Realities and Representations in Medieval Flanders, 900-1100 (Ithaca, NY: Cornell University Press, 2013), 3-8.

${ }_{5}^{5}$ Vanderputten, Monastic Reform as Process, 5.

${ }^{6}$ See Vanderputten, Monastic Reform as Process, 4-6.

${ }^{7}$ Anne-Marie Helvétius, Abbayes, évêque et laïques: une politique du pouvoir en Hainaut au moyen âge (VIIe-XIe siècle) (Brussels: Crédit Communal, 1994); Steffen Patzold, Konflikte im Kloster: Studien zu Auseinandersetzungen in monastischen Gemeinschaften des ottonisch-salischen Reichs (Husum: Matthiesem Verlag, 2000); John Nightingale, Monasteries and Patrons in the Gorze Reform: Lotharingia c.850-1000 (Oxford: Clarendon Press, 2001); Vanderputten, Monastic Reform as Process.
} 
Frankish monastery with an even relatively substantial corpus of documents, Saint-Vincent in Laon, the abbey's reform seems to have depended on an alliance between Bishop Roric of Laon and the Irish monk Macallan: Macallan could depend on Roric's patronage to look out for his house's interests. ${ }^{8}$ Similar patterns can be seen in Flanders and in Anjou. ${ }^{9}$

A further difference can be seen in the circumstances of the reform of Homblières in 949 , in the middle of some turbulent decades in French history. ${ }^{10}$ King Louis IV, who had returned to the throne in 936, had quarrelled with Hugh the Great, duke of the Franks, and the subsequent war had continued for years. ${ }^{11}$ In 945 , Louis had been captured by Vikings and sold to Hugh the Great. ${ }^{12}$ Subsequently, he had only been restored to the name of king in return for surrendering his last remaining stronghold at Laon. ${ }^{13}$ Only by the intervention of his brotherin-law, Otto the Great, king of Germany, in 946, was he returned to independent action. ${ }^{14}$

The archiepiscopal see of Rheims was also in turmoil. The see was disputed between two claimants, Hugh, who had been imposed on it at the age of five by his father Heribert II in 925; and Artald, a monk of Saint-Rémi, who had been imposed by King Ralph in $931 .{ }^{15}$ Hugh had been returned to his see and deposed again in 946. This dispute, which was still live in the late 940s, as well as the quarrels between Hugh the Great and Louis, fed into one another, and feelings ran high. ${ }^{16}$ The consequence of this was that the province of Rheims, in the mid-tenth century, was unstable and often violent.

The counties under the comital family of Vermandois itself were undergoing some restructuring. ${ }^{17}$ The death of the notorious count Heribert II in 943 had led to the partition of

\footnotetext{
${ }_{8}^{8}$ Annie Dufour-Malbezin, ed., Actes des évêques de Laon: des origines à 1151 (Paris: CNRS, 2001), 79-84 (nos. 7-10); see also Heinz Löwe, 'Dialogus de statu sanctae ecclesiae: Das Werk eines Iren im Laon des 10. Jahrhunderts', Deutsches Archiv für Erforschung des Mittelalters 17 (1961): 42-6.

${ }^{9}$ For Flanders, see in the first instance Steven Vanderputten, 'Flemish Monasticism, Comital Power and the Archbishops of Canterbury: a Written Legacy from the Late Tenth Century', in England and the Continent in the Tenth Century: Studies in Honour of Wilhelm Levison (1876-1947), eds. David Rollason, Conrad Leyser and Hannah Williams (Turnhout: Brepols, 2010), 72; Vanderputten, Monastic Reform as Process, 31-49; for Anjou, see Bernard S. Bachrach, 'Geoffrey Greymantle, Count of the Angevins, 960-987: a Study in French Politics', in idem, State-Building in Medieval France: Studies in Early Angevin History (Aldershot: Variorum, 1995), III, 16, 30, 36-8; idem, 'Fulk Nerra's Exploitation of the Facultates monachorum, ca. 1000 ', in idem, State-Building in Medieval France, VIII, 31.

${ }^{10}$ For an overview of West Frankish history in this period, see Karl Ferdinand Werner, Histoire de France, vol. 1, Les origines (avant l'an mil) (Paris: Fayard, 1984), 431-96.

${ }_{11}$ The main and in most cases the only narrative source for this is Flodoard of Rheims, Annales: Philippe Lauer, ed., Les annales de Flodoard (Paris: Alphonse Picard et fils, 1905); the major study of Louis' reign is still Philippe Lauer, Le règne de Louis IV d'Outre-Mer (Paris: É. Bouillon, 1900).

${ }^{12}$ Flodoard, Annales, 98-101; see also Dudo of Saint-Quentin, De moribus et actis primorum Normanniae ducum, ed. Jules Lair (Caen: F. Le Blanc-Hardel, 1865), 243-7.

${ }^{13}$ Flodoard, Annales, 101.

${ }^{14}$ Flodoard, Annales, 101-3.

${ }^{15}$ The main source other than Flodoard's Annales for this is Book IV of his own history of the church of Rheims: Flodoard of Rheims, Historia Remensis ecclesiae, ed. Martina Stratmann. MGH Scriptores 36 (Hanover: Hahnsche Buchhandlung, 1998). For commentary on this work, see in general Michel Sot, Un historien et son église au Xe siècle: Flodoard de Reims (Paris: Fayard, 1993), especially 261-94; see also Jason Glenn, Politics and History in the Tenth Century: the Work and World of Richer of Reims (Cambridge: Cambridge University Press, 2004), 60-80; in general, see Rosamond McKitterick, 'The Carolingian Kings and the See of Rheims', in Ideal and Reality in Frankish and Anglo-Saxon Society, ed. Patrick Wormald, with D. Bullough and Roger Collins (Oxford: Blackwell, 1983), 234-8.

${ }^{16}$ See the visions of Flothild, a young woman of the archdiocese caught up in the fighting, printed as Appendix II in Flodoard, Annales, 168-76.

${ }^{17}$ Michel Bur, La formation du comté de Champagne v. 950-v.1150 (Nancy: Université de Nancy II, 1977), 97-9, for what follows.
} 
his domain between his children. Saint-Quentin itself was under the rule of his second son, Albert, known as 'the Pious', but Heribert's other children, such as his eldest son Heribert the Elder, also maintained some stake in acting as a group. ${ }^{18}$ Moreover, Heribert II's sons also maintained ties to their brother, the deposed archbishop Hugh, as late as $962 .{ }^{19}$ As a group, the sons of Heribert II were drifting into becoming allies of the king, but there was still potential for tension.

It was in this context that Homblières was reformed in 949. In the decades which followed, the abbey produced two sets of sources. The first set, and that with which this article is the more concerned for most of its discussion, is the monastery's cartulary. This is a twelfth-century production, but one which preserves 22 tenth-century charters. ${ }^{20}$ This is not an unheard-of level of preservation for northern France as a whole, but it is the largest set of charters to survive from Picardy. The second set of sources consists of two hagiographical texts, the Vita sanctae Hunegundis and a combined Translatio and Miracula. ${ }^{21}$ Both were written by Abbot Berner in the $950 \mathrm{~s}$, although the Miracula was added to later, in the $960 \mathrm{~s}$ or $970 \mathrm{~s}^{22}$ These texts had a dual function in celebrating and publicising St Hunegund's miraculous powers: first, creating and developing a sense of identity within the community at Homblières; and second, acting as an exercise in public relations with an intention to encourage donations to the monastery. It is the latter function with which this article is the more concerned.

The Vita, Translatio and Miracula indicate the first way in which Homblières was different from other monasteries. Homblières was originally a nunnery and by 946 it seems to have been thought in need of reform. In that year, Archbishop Artald imposed a new abbess, named Bertha, on the nuns, and the body of St Hunegund was translated into the abbey. However, in 949 (by which time Bertha was probably dead), the community of nuns was replaced with a community of monks. ${ }^{23}$

In this light, the Vita and the Translatio represent an unusual rhetorical strategy. In other reformed communities, historians from the first generation of reform, writing within a few decades of the event, tended to position their communities in opposition to what was there before. This tendency is most pronounced in Folcuin of Saint-Bertin, who tells us that the canons of that place fled all the way to Bath rather than join the reformers. ${ }^{24}$ Nonetheless, there are other examples. Ralph Glaber's life of William of Volpiano creates a clear rhetorical

\footnotetext{
${ }^{18}$ E.g. Flodoard, Annales, 92.

${ }^{19}$ Flodoard, Annales, 150-1.

${ }^{20}$ Evergates, ed., Cartulary of Homblières, 20, n. 101, for an interesting suggestion by the text's original editor, William Newman, that there may have been a late tenth- or early eleventh-century cartulary; the later cartulary is discussed by Brigitte Bedos-Rezak, 'Towards an Archaeology of the Medieval Charter: Textual Production and Reproduction in Northern French Chartriers', in Charters, Cartularies and Archives: the Preservation and Transmission of Documents in the Medieval West, eds. Adam Kosto and Anders Winroth (Toronto: Pontifical Institute of Medieval Studies, 2002), 50-1.

${ }^{21}$ Berner of Homblières, Vita S. Hunegundis, in Acta sanctorum, Aug. V (Antwerp: Bernadus Albertus vander Plassche, 1741), 227-31; Berner of Homblières, Translatio corporis S. Hunegundis una cum miraculis, in Acta sanctorum, Aug. V, 232-7.

${ }^{22}$ See Evergates, ed., Cartulary of Homblières, 3, n. 8, for the dates of these texts; see also Van der Straeten, 'Sainte Hungeonde d'Homblières', 52.

${ }^{23}$ Evergates, ed., Cartulary of Homblières, 2-3; on reform of female houses in a wider perspective, see Michel Parisse, Religieux et religieuses en Empire du Xe au XIIe siècle (Paris: Picard, 2011), 200-14, although the replacement of a female community by a male one makes the Homblières case different from most of these examples.

${ }^{24}$ Folcuin, Gesta abbatum Sithiensium, ed. Oswald Holder-Egger. MGH, SS 13 (Hanover: Hahnsche Buchhandlung, 1881), 628-9; see the comments of Karine Ugé, Creating the Monastic Past in Medieval Flanders (York: York Medieval Press, 2005), 31.
} 
distance between the holy William and the carnal community of pre-reform canons. ${ }^{25}$ Even the Miracula produced by Homblières' neighbour, the monastery of Saint-Quentin-en-l'Isle, mentions that before a reform abbot was introduced, various people tried to buy the abbacy and that the canons who lived there were thrown out. ${ }^{26}$

By contrast, Berner's narration actively strives to create continuity with the recent past. Berner emphasises Abbess Bertha's holiness and piety and the translation of Hunegund's body is not anything done by the monks, but by Bertha. ${ }^{27}$ Indeed, the replacement of the nuns by monks is not mentioned in the narrative. Moreover, the Translatio is complemented by the cartulary. The first charter in the collection is an act of Bishop Transmar of Noyon, approving Bertha's translation of the holy body, a charter which the monks then preserved or may even have fabricated. $^{28}$

For communities of monks which replaced communities of nuns, writing themselves into the early history of the abbey was common. In the abbey of Maubeuge, for instance, incoming male religious in the late tenth century forged a Merovingian royal diploma, which specified the lands granted to the male community at the monastery, to legitimise their takeover of the abbey and, as importantly, to justify their claims to the nuns' property. ${ }^{29}$ Similarly in Marchiennes, Abbot Leduin began to emphasise St Jonat and St Mauront, the first abbot of Marchiennes and the son of its founder St Rictrude respectively, in order to shift the balance of saintly patronage of the abbey away from its former, female, patrons, St Rictrude and St Eusebia. ${ }^{30}$

Indeed, Berner himself did this. In Hunegund's Vita, the climactic episode is the volte-face of Eudald, Hunegund's fiancé, who then endows Homblières with the goods which he would have given to her in dowry. ${ }^{31}$ Having previously been the main antagonist of much of the Vita, he becomes the monastery's agent in secular affairs and Hunegund's closest friend, thus placing men at the very beginning of Homblières' existence and emphasising a continuity of holiness.

However, what is distinct about Homblières' situation is that Berner's writings maintain continuity of holiness not only with the distant past, but also with the immediate past, with his own predecessor. This is unusual in the context of reforming an institution. The most common - almost ubiquitous - narrative is that the monastery was founded in holiness, became corrupt, and then was restored to its pristine condition. ${ }^{32}$ Berner's Translatio omits the corruption: indeed, the reader who did not know that the monastery had been reformed in 949 would not discover it from the Translatio.

This evidence should be placed side-by-side with the charter of Louis IV confirming the monks' replacement of the nuns. ${ }^{33}$ According to Louis, the nuns were 'living insufficiently honestly therein, and were unwilling to be subjected to regular rule'; therefore, 'monks who

\footnotetext{
${ }^{25}$ Ralph Glaber, Life of Saint William, in Rodulfus Glaber Opera, ed. and trans. John France with Neithard Bulst and Paul Reynolds (Oxford: Clarendon Press, 1989), 270-3.

${ }^{26}$ Miracula S. Quintini in cenobio Insulensi patrata, in Acta sanctorum Oct. XIII (Paris: Victor Palmé, $1883), 813$.

${ }^{27}$ Berner, Translatio, 233-4.

${ }^{28}$ Evergates, ed., Cartulary of Homblières, 35-7 (no. 1).

${ }^{29}$ Helvétius, Abbayes, évêque et lä̈ques, 247-52.

${ }^{30}$ Vanderputten, Monastic Reform as Process, 135-42.

${ }^{31}$ Berner, Vita, 231.

${ }^{32}$ Nightingale, Monasteries and Patrons, 15-17, on this archetypal narrative; see also Patzold, Konflikte im Kloster, 200-11.

${ }^{33}$ Philippe Lauer, ed., Recueil des actes de Louis IV roi de France (936-954) (Paris: Imprimerie Nationale, 1914), 76-7 (no. 32).
} 
obeyed a rule and an abbot were substituted. ${ }^{34}$ Berner's Vita and Translatio (as well as all of the Homblières charters), however, simply do not mention lax standards on the part of the nuns as a community. Any discipline problems are written out of history, as the focus is put on Bertha's merits. ${ }^{35}$ Denunciations of the immediate past are a common trope in reform discourse, ${ }^{36}$ and the consensus among historians is that they should not be taken at face value. However, if always taking them at face value is certainly foolish, never doing so under any circumstances is also perhaps a risky approach.

Homblières was reformed twice in three years. The very short timescale, and the fact that the same reformer - Artald of Rheims - was involved in both, may perhaps imply that the poor discipline of the community had some reality outside Louis' charter; that, having tried one reform which failed, another was thought to be necessary. Indeed, the fact that Berner's works do not pick up on this discourse is itself significant: the intent of his writings seems to be not defending the reform, but giving the abbey an unblemished record of effective holiness, including in the recent past. ${ }^{37}$ Hunegund blessed people with her miracles when she was alive, she blessed people with them in the immediate past, and she blesses people with them in Berner's present. The intent looks a lot more like sustaining the holiness of the saint through a period of poor discipline by the previous community than attempting to justify their replacement.

This is not to imply that the experience of Homblières was typical. However, the relationship of reform discourse to reality should be seen as a spectrum. If, as Nightingale has shown convincingly, the claims of Bishop Adventius of Metz about the poor condition of the monastery of Gorze in 863 were little more than a rhetorical device in a power struggle over the monastery between the bishop and Count Bivin, this would represent one end of the spectrum. ${ }^{38}$ However, it is possible that some representations of monastic decline are at the other end of the spectrum: that is, that some abbeys really were in a bad condition. If this possibility is considered, it seems likely that Homblières may be an example of it.

It is hard to generalise about the motives of those behind the replacement of the female community with a male one. If Homblières did have a crisis of discipline, this was an uncommon occurrence. In any case, the lack of information about the community at Homblières before 946 means that there is no evidence, even for speculation. However, if Hunegund's credibility as an effective saint was damaged by lax standards among her community, then restoring it would have been a matter of some importance. The effective channelling of holy power was one of the key ways in which monasteries attracted patronage, of which the community at Homblières was sorely in need. ${ }^{39}$ Homblières was a materially poor monastery. Usually referred to as a cella, occasionally Homblières is specified as a 'small place'. ${ }^{40}$ The papal privileges which confirmed Homblières' endowment support this impression: in the 950s,

\footnotetext{
34 'Quibusdam sanctimonialibus inibi non satis honeste viventibus et regulari districtioni subjici, nolentibus inde remotis substituerentur monachi qui obedirent regulae et abbati ...' ': Lauer, ed., Recuiel des actes de Louis IV, 77.

${ }^{35}$ Berner, Translatio, 233.

${ }^{36}$ See notes $24-6$.

${ }^{37}$ Hence Berner, Vita, 232, finishes with Hunegund's death; and Berner, Translatio, 233, begins with Bertha's holiness and ends, 236, in the 960s.

${ }^{38}$ Nightingale, Monasteries and Patrons, 31-3.

${ }^{39}$ For the relationship between holy power and gifts to monasteries, see Barbara Rosenwein, To Be the Neighbor of Saint Peter: the Social Meaning of Cluny's Property 909-1040 (Ithaca, NY: Cornell University Press, 1989), 76-7, 137-9.

${ }^{40}$ Evergates, ed., Cartulary of Homblières, e.g. 40 (no. 3), 41 (no. 4), 53 (no. 12), 66 (no. 21), for examples of Homblières as a cella in the acts of four separate issuers, as well as 65 (no. 20), for Homblières as a parvo locello; noted by Evergates, ed., Cartulary of Homblières, 4, n. 13.
} 
Homblières had property in only a few places in the local area and a couple outside it. ${ }^{41}$ Comparing these confirmations to those for other, wealthy, monasteries, such as Saint-Martin of Tours or SaintCroix of Orleans, Homblières was much poorer. ${ }^{42}$ Therefore, in writing to attract donations, Berner was, among other things, acting to consolidate his monastery's material resources; in this, he was not different from other communities, both reformed and not. ${ }^{43}$

In addition to reinforcing the holy power of the saint, the abbey's charters show a concern on Berner's part to support his monastery's patrimony through consolidation and land transactions. By the end of Berner's rule, Homblières' landholdings fell into three main groups (Figure 1). First, there was a group of properties situated less than 10 miles to the north of the monastery, of which the most important was Fresnoy-le-Grand. Second, there was a group found slightly further to the south, of which the most important was Remigny. Third and finally, there was a small group centred on Homblières itself.

Remigny and Homblières both provide examples of this strategy of consolidation. Remigny was almost certainly not part of Homblières' original patrimony, as it was mentioned in neither the papal privilege issued by Agapitus II in 954 or 955, nor the privilege issued by John XII on 2 January $956 .{ }^{44}$ Its first mention comes in a charter of 4 July 956, in which one Wallo gives four allodial mansi in the villa to Homblières. ${ }^{45}$ Subsequently, in 959, Berner petitioned the West Frankish Queen Gerberga for permission to purchase three more mansi there, which belonged to a nunnery which the queen owned in Soissons. ${ }^{46}$ Finally, he petitioned Count Heribert the Elder to buy two further mansi which were owned by the monastery of SaintMédard in Soissons, of which Heribert was lay abbot. ${ }^{47}$

In the villa of Homblières itself, the abbey also expanded its property. The villa of Homblières was confirmed as a possession of the monastery by both its papal privileges. ${ }^{48}$ In a charter which is undated, but which, based on the witness list, was probably issued in the late 960s or early 970s, he acquired an unknown place called Rothliacus near (situm in vicinio) Homblières. ${ }^{49}$ Again, in 982 , Berner consolidated the abbey's property by an exchange of fields within the villa. ${ }^{50}$

The small scale of these properties is very interesting. In the last case, it implies that Berner was interested in managing his property portfolio down to the individual fields. ${ }^{51}$ This astute estate management indicates the role an abbot could play as a manager of community resources. Active management of monastic property was not unique to Homblières, although this kind of evidence is not present in most other northern French cartularies and charter collections. ${ }^{52}$ Homblières' tenth-century charters are one of the few instances in the West

\footnotetext{
${ }^{41}$ Evergates, ed., Cartulary of Homblières, 41-5 (nos. 5-6); see also 7 (fig. 2).

${ }^{42}$ Compare Homblières' papal privileges to the lists of properties in Recueil des historiens des Gaules et de la France, vol. 10 (Paris: Victor Palmé, 1874), 556-9, issued by Hugh Capet for Saint-Croix, and 550-2, which he issued for Saint-Martin.

${ }^{43}$ See Ugé, Creating the Monastic Past), 119-26, for parallel concerns at Marchiennes.

${ }^{44}$ See note 41.

${ }^{45}$ Evergates, ed., Cartulary of Homblières, 45-6 (no. 7).

${ }^{46}$ Evergates, ed., Cartulary of Homblières, 46-7 (no. 8).

${ }^{47}$ Evergates, ed., Cartulary of Homblières, 52-4 (no. 12).

48 See note 41.

${ }^{49}$ Evergates, ed., Cartulary of Homblières, 59-60 (no. 16); compare with the witness list of 55 (no. 13); see the comments at 60, n. 1 .

${ }^{50}$ Evergates, ed., Cartulary of Homblières, 60-2 (no. 17).

51 'Commutationem de tribus campellis ... simplum accipiens et duplum reddens': Evergates, ed., Cartulary of Homblières, 61 (no. 17).

${ }_{52}$ Michèle Gaillard, D'une réforme à l'autre (816-934): les communautés religieuses en Lorraine à l'époque carolingienne (Paris: Publications de la Sorbonne, 2006), 87-111.
} 
Key

Property of Homblières

Major location

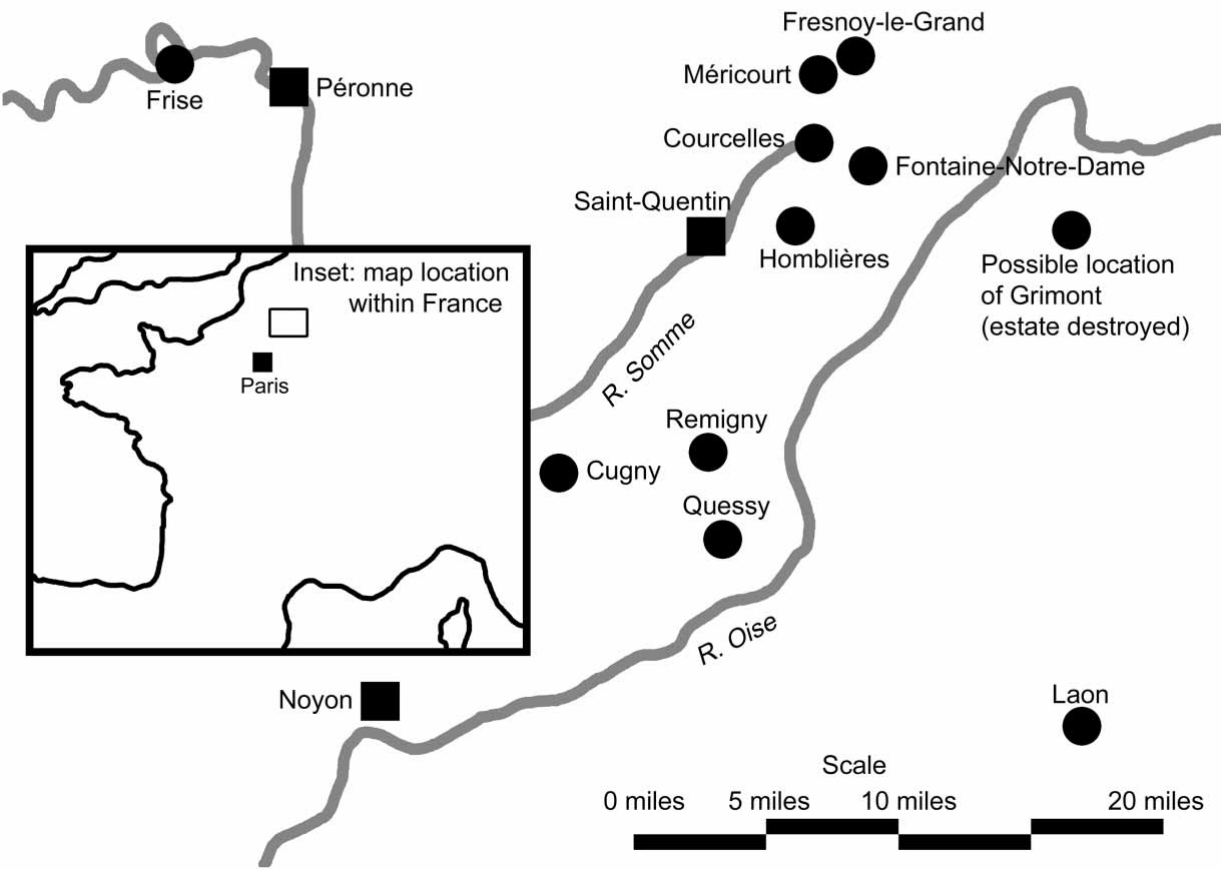

Figure 1. Possessions of Homblières during the reign of Abbot Berner.

Source: Author

Frankish kingdom where an abbot can be seen to take an interest in the nitty-gritty of land consolidation, management and exchange. In this sense, the charter collection is a window into the kind of detailed oversight of monastic property in which most abbots probably engaged.

In addition to acquiring new land, the community also had to defend the land it already held against potential challengers, a situation complicated by the lack of a single major patron. Eilbert of Florennes, a nobleman who held land in Lotharingia and Vermandois, the original owner of Homblières, and one of the major forces behind its reform, does not seem to have developed close ties with the new community. ${ }^{53}$ Eilbert did remain the monastery's ally. In a charter dated 988, for instance, he is referred to as facilitating the arrival of an oblate and his land at Homblières. ${ }^{54}$ However, he appears in relatively few of the monastery's charters, and only as a witness when he himself was involved in a transaction with the monastery. ${ }^{55}$ It is probable that

\footnotetext{
${ }^{53}$ For Eilbert, see Daniel Misonne, Eilbert de Florennes: histoire et légende (Louvain: Publications universitaires de Louvain, 1967), 6-43.

${ }^{54}$ Evergates, ed., Cartulary of Homblières, 63 (no. 19).

${ }^{55}$ Evergates, ed., Cartulary of Homblières, 54-5 (no. 13), in which one Heilbert is the actor, 59-60 (no. 16) in which Eilbert has a transaction approved by Albert the Pious, and 63-4 (no. 19); Georges Despy, Les chartes de l'abbaye de Waulsort: étude diplomatique et édition critique, vol. 1 (Brussels: Palais des academies, 1957), 188, does not think the Heilbert in no. 13 is Eilbert of Florennes: the question is debatable.
} 
Eilbert's possessions were too scattered and for the most part too far away for him to have much to do with Homblières and, whether for good or for ill, he was not an important neighbour for the monastery. Similarly, the archbishops of Rheims are not recorded as having anything to do with the monastery after 949 .

This lack of a chief patron had some potential problems. First, the absence of a particular protector could leave the abbey vulnerable to challenges to its property. The possibility of violence should not be underestimated: as mentioned above, the mid-tenth-century ecclesiastical province of Rheims was in a state of some disruption. ${ }^{56}$ In the year of the arrival of a male community in Homblières, the deposed Archbishop Hugh and his men captured Omont, an estate and fortress owned by the church of Rheims, and used it as a base to ravage nearby villae. ${ }^{57}$ Flodoard's Annals are filled with similar stories: in 954, for instance, Count Heribert the Elder, Hugh's brother, captured Rheims' property at Roucy. ${ }^{58}$ While Archbishop Artald was not to be deposed from his see again, and violence died down after the mid-950s, the community of Homblières could not have expected this in $949 .{ }^{59}$

Even without violence, however, there was potential for the holdings of Homblières to be challenged through litigation. ${ }^{60}$ It should be noted that Homblières was not distinct from other landowners in the area, either lay or ecclesiastical, in either of these dangers to its property holding. However, as a poor community without the backing of a powerful lord, Homblières needed to take other precautions to secure its property. It seems to be for this reason that Homblières, in the second quarter of the tenth century, produced what by the standards of the eastern West Frankish kingdom is an unusually large collection of charters.

For instance, in January 963, the West Frankish King Lothar issued a charter confirming the grant of the estate of Quessy made by Count Arnulf the Great of Flanders. ${ }^{61}$ This estate, just over 12 miles south of Saint-Quentin, presumably came to Arnulf in dowry from his wife Adele, a daughter of Count Heribert II of Vermandois. ${ }^{62}$ The confirmation of the grant through a royal charter would seem to be specifically aimed at giving the monastery's possession of the estate legitimacy in the face of a potential challenge from Adele's family, the counts of Vermandois. In 963, Arnulf was old and sick, unlikely to live very long, and a charter from Lothar, in addition to the intrinsic prestige benefits of a royal diploma, would have been more likely than one from Arnulf to carry with it the power of an effective supporter. ${ }^{63}$ The 963 diploma was sought and acquired by the community because it had potential to bring real support to Homblières should its claim to the estate require defence.

A similar case can be made for a diploma, dated to 26 March 963, issued by Count Heribert the Elder to the monastery. In it, he confirmed a purchase made by Abbot Berner of land in

\footnotetext{
${ }^{56}$ See note 16 .

${ }^{57}$ Flodoard, Annales, 121-2.

${ }^{58}$ Flodoard, Annales, 139.

${ }^{59}$ Flodoard's Historia Remensis ecclesiae provides a parallel case of the relationship between writing and ecclesiastical property holding at this time and place: see Edward Roberts, 'Flodoard, the Will of St Remigius and the See of Rheims in the Tenth Century', Early Medieval Europe 22 (2014): 213-18.

${ }^{60}$ See the essays in Wendy Davies and Paul Fourace, eds., The Settlement of Disputes in Early Medieval Europe (Cambridge: Cambridge University Press, 1986), especially Janet Nelson, 'Dispute Settlement in Carolingian West Francia', 45-64; and Wendy Davies, 'People and Places in Dispute in Ninth-Century Brittany', 65-84.

${ }^{61}$ Lothar, Acta, in Louis Halphen, ed., Recueil des actes de Lothaire et de Louis Vrois de France (954-987) (Paris: Imprimerie Nationale, 1908), 38-9 (no. 18).

${ }^{62}$ Witger, Genealogia Arnulfi comitis, ed. L.C. Bethmann. MGH SS 9 (Hanover: Hahnsche Buchhandlung, 1851), 303.

${ }^{63}$ See Jean Dunbabin, 'The Reign of Arnulf II, Count of Flanders and its Aftermath', Francia 16 (1989): 54.
} 
Remigny. ${ }^{64}$ This land was from the jurisdiction of Saint-Médard, of which Heribert was lay abbot; it was also from the benefice of Albert the Pious, count of Vermandois, Heribert's brother, and held by his fidelis Madalger. ${ }^{65}$ This has been seen as evidence of a tenurial hierarchy. Indeed, Bur's argument for tenurial hierarchies in tenth-century Champagne rests heavily on this charter. ${ }^{66}$ Evergates argues, in his introduction to the edition of Homblières' cartulary:

A tenurial hierarchy appears to have been firmly established at that time: knights held benefices from the count's direct vassals (his fideles), who in turn held their benefices from the count ... only the count could authorise the formal grants of alienation. ${ }^{67}$

That is to say, the man at the top of the hierarchy had to confirm these transactions for them to have any validity. In this case, Madalger held the land from Albert, who held it from Heribert, whose confirmation as lay abbot was what was ultimately required for the transaction to have validity. This seems an incomplete explanation, however. First, it is not clear that transactions involving abbey land needed the approval of the abbot, lay or otherwise. Another charter in the cartulary, dated to 27 February 960, shows the canons of Saint-Quentin granting abbey land to the monks of Homblières in their own name. ${ }^{68}$ Count Albert, the lay abbot of SaintQuentin, signs as a witness, but there is no indication in the document that his confirmation was necessary, as opposed to his support being welcome. ${ }^{69}$ This seems to indicate that it was possible that the brothers of a monastery could grant land validly in their own name, without explicit confirmation by the abbot.

A further noteworthy feature of the 963 charter of Heribert the Elder is that neither Albert the Pious nor Madalger the fidelis appear in the witness list. ${ }^{70}$ It is possible that both of them had given their consent elsewhere and not had it recorded. However, as there is no sign of it otherwise, the possibility must be considered that this charter represents a kind of legal weapon which Berner could use against them - that is, it is possible that, in his quest to consolidate Homblières' possessions in Remigny, and with neither Albert nor Madalger willing to grant their land to him, Berner went to a third party with an interest in the land who was willing to give him a claim to the land, a claim which he could then exploit to actually gain control of it. ${ }^{71}$

However, Albert the Pious posed a greater threat to the monastery than simply his potential claims on some of Homblières' land. Perhaps more important than his comital title, Albert was the lay abbot of the important abbey of Saint-Quentin. Saint-Quentin was close to Homblières - at around 4 miles as the crow flies, it was well within a day's walk there and back. It was also a major ecclesiastical centre for the region, and involved in the reform or foundation of a number of monasteries in Vermandois. Albert sent canons of Saint-Quentin to reform the monasteries of Saint-Quentin-en-l'Isle, Saint-Prix and probably Mont-Saint-Quentin as well. ${ }^{72}$

\footnotetext{
${ }^{64}$ Evergates, ed., Cartulary of Homblières, 52-4 (no. 12).

${ }^{65}$ Evergates, ed., Cartulary of Homblières, 53 (no. 12).

${ }^{66}$ Bur, Comté de Champagne, 399.

${ }^{67}$ Evergates, ed., Cartulary of Homblières, 6, following Bur, above.

${ }^{68}$ Evergates, ed., Cartulary of Homblières, 49-51 (no. 10): 'tres mansos nostrae communis possessionis'.

${ }^{69}$ Evergates, ed., Cartulary of Homblières, 50 (no. 10): 'Signum Alberti comitis et abbatis'.

${ }^{70}$ Evergates, ed., Cartulary of Homblières, 54 (no. 12).

${ }^{71}$ In this sense, it shares much of the function of a forged charter, despite being genuine: see Marco Mostert, 'Forgery and Trust', in Strategies of Writing: Studies on Text and Trust in the Middle Ages, eds. Petra Schulte, Marco Mostert and Irene van Renswoude (Turnhout: Brepols, 2008), 53; Wendy Davies, 'Forgery in the Cartulaire de Redon', in Fälschungen im Mittelalter: internationaler Konreß der Monumenta Germaniae historica, München 16.-19. September 1986 (Hannover: Hahn, 1988), 275.

${ }^{72}$ Eric Christiansen, introduction to Dudo of Saint-Quentin, De moribus, x, n. 5.
} 
In all these instances, the abbey ended up moving closer into dependence on Albert and on Saint-Quentin. This is most easy to demonstrate for Saint-Quentin-en-l'Isle. In a charter issued by Albert for this abbey, he refers to Saint-Quentin itself as the 'principal church' (principalis ecclesia), indicating the superiority of the main church of Saint-Quentin over Saint-Quentinen-l'Isle. ${ }^{73}$ Albert himself had appointed Anselm, the first abbot of Saint-Quentin-en-l'Isle after its reform, and it is likely that the second abbot, Arnold, was also his nominee. ${ }^{74}$ This was a potential threat to Homblières because the community at Saint-Quentin had been heavily involved in its original reform under Abbess Bertha. Berner's Translatio of St Hunegund, for instance, records the close involvement of Giso, the custodian of Saint-Quentin, in moving St Hunegund's body. ${ }^{75}$

There are indications that Albert's consent to the reform of Homblières was not necessarily voluntary. Louis IV's charter describing the reform implies the chief force behind the monastic reform was Eilbert of Florennes, who possessed the monastery before its reform. With a congregation of monks already established by Eilbert and placed under a regular abbot, Louis' intervention was requested. However, Eilbert did not give the monastery directly to the king. Instead, he restored (reddidit) the abbey to Albert, who in turn gave it up to the king's authority. ${ }^{76}$ By involving Albert in this way, Louis and Eilbert were making Albert publicly act as a witness to and supporter of the reform, even though it may have reduced the influence of Saint-Quentin on Homblières and therefore gone against Albert's own interests.

Albert should be seen as the head of an ecclesiastical network controlled from Saint-Quentin. Homblières, despite its physical proximity, was not part of that network. Instead, the impetus for its reform had come from different ecclesiastical power groups, from Eilbert of Florennes and his wife, whose major monastic projects, Bucilly, Waulsort and Saint-Mihiel, were otherwise in Lotharingia; and from the archbishops of Rheims, whose other reform projects, including Saint-Rémi of Rheims and Saint-Basle of Verzy, lay largely around the city of Rheims itself. ${ }^{77}$ There was a possibility that, were Homblières to be inveigled into Albert's ecclesiastical network, it would lose its autonomy.

Even if this suggestion is rejected, Albert was still the abbot of Homblières' most important neighbour and the local count, and need not have taken its side in the event that property rights were disputed. Albert was fully able to interfere with monastic affairs within his county. Having his approval for Homblières' transactions would make any later defence of the property, should it be necessary, easier. In the cartulary, there are five charters confirming land exchanges issued in Albert's name. Albert himself had a direct interest in only one of these. ${ }^{78}$

Again, it seems unlikely that this was a question of hierarchy of tenure. Two charters from the 980s are important here. In the first, issued in 982, Albert confirms an exchange of fields made between Berner and three men of Saint-Quentin (hominibus Sancti Quintini), as well as a

\footnotetext{
${ }^{73}$ Louis P. Colliette, Mémoires pour server a l'histoire ecclésiastique, civile et militaire de la province du Vermandois, vol. 1 (Cambrai: Samuel Berthoud, 1771), VII, 569 (no. 15).

${ }^{74}$ Miracula $S$. Quintini in coenobio Insulensi patrata, 813.

75 Berner, Translatio, 233.

${ }^{76}$ Lauer, ed., Recueil des actes de Louis IV, 77.

${ }^{77}$ For Eilbert, see Misonne, Eilbert de Florennes, 9-10 for Saint-Michel, 12 for Bucilly, 14 for Waulsort; for Waulsort, see also Despy, L'abbaye de Waulsort; for Rheims, see Michel Bur, 'Saint-Thierry et le renouveau monastique dans le diocèse de Reims au Xe siècle', in Saint-Thierry: un abbaye du VIe au XXe siècle, ed. Michel Bur (Saint-Thierry: Association des amis de l'Abbaye de Saint-Thierry, 1979), 40, for Archbishop Hugh's reform of Saint-Rémi; for Archbishop Artald's reform of Saint-Basle, see Flodoard, Annales, 134; in general, see also Josef Semmler, 'Das Erbe der karolingischen Klosterreform in 10. Jahrhundert', in Monastische Reformen, eds. Kottje and Maurer, 73.

${ }^{78}$ Evergates, ed., Cartulary of Homblières, 48-9 (no. 9), where Albert acts directly as abbot of Saint-Quentin.
} 
subsequent exchange of tithes made between Homblières and Saint-Quentin. ${ }^{79}$ In the second, also issued in 982, he confirms an exchange made with Dudo, who appears in a number of places in the cartulary and is called variously vassallus and miles, concerning the benefice of one Ralph. ${ }^{80}$ There is no indication in either of these that any of the men concerned held their land from Count Albert.

If, therefore, it seems unlikely that Albert had to confirm a transaction for it to be valid, why did the parties seek his confirmation? The most likely hypothesis is that Homblières deliberately accumulated a large number of charters confirmed by the most powerful magnate in the immediate vicinity because Albert's support for a transaction would lend it extra weight if it were to be challenged, as well as providing some guarantee that he would not challenge it himself. ${ }^{81}$ His confirmation was not actually needed to make the transaction valid.

The language of the charters themselves seems to confirm this. Albert is repeatedly made to say not that his assent was necessary, but that his authority buttresses what has already taken place. Hence, we find him asked whether 'our authority might strengthen the aforesaid transaction [made between Berner and Eilbert of Florennes]', 82 and again, whether 'we might confirm with our authority a certain transaction which had been made' ${ }^{83}$ That is, in both these cases, the transaction had already happened, and Albert's authority merely lent it extra weight.

Each charter issued in Albert's name, some of which concern small pieces of land, down to the level of individual fields, was a piece of evidence which demonstrated that he had consented if he were ever to try and challenge the transaction, both at the time and in the future. Unfortunately, there is no outside indication when Albert's confirmation was thought to be needed, and there is no pattern within the charters themselves. Nonetheless, the most likely motor for this accumulation of these charters in general was fear of challenges to the monastery's landholdings.

The chronology of these documents is interesting. Only four charters, of which one may be a forgery, can be dated to the last 12 years of Berner's abbacy, 970-82, compared with 12 charters issued between 949 and 970. Moreover, in the 61 years between 982, when Berner died, and 1043 - the death of Count Otto of Vermandois, the grandson of Albert the Pious - there were 11 charters issued which are still extant, at least one of which is at best interpolated and very probably forged. ${ }^{84}$ Berner's immediate successor, Alberic, appears in only one charter - the absence of documentation seems to have been typical of his abbacy. ${ }^{85}$ In a charter probably datable to the late $1020 \mathrm{~s}$ or early $1030 \mathrm{~s}$, a later abbot, Waleran, bemoaned 'the negligence of his ancestors' in the matter of acquiring written confirmation of transactions, in this case specifically referring to a gift made by one Castellan Lambert during Alberic's time. ${ }^{86}$

\footnotetext{
${ }^{79}$ Evergates, ed., Cartulary of Homblières, 59-61 (no. 17).

${ }^{80}$ Evergates, ed., Cartulary of Homblières, 6 (no. 18); for Dudo, see 49 (no. 9), where Dudo appears without a title, 62 (no. 18), where he signs as Budonis vassalli; 65 (no. 20), as Budonis militis.

${ }^{81}$ See the comments of Philippe Depreux, 'The Development of Charters Confirming Exchange by the Royal Administration (Eighth-Tenth Centuries)', in Charters and the Use of the Written Word in Medieval Society, ed. Karl Heidecker (Turnhout: Brepols, 2000), 61, in relation to kings.

82 Evergates, ed., Cartulary of Homblières, 60 (no. 16): 'ut praedicta commutatio nostra authoritate roboraretur'.

${ }^{83}$ Evergates, ed., Cartulary of Homblières, 40 (no. 3): 'ut quamdam commutationem quam inter se fecerunt nostra authoritate firmaremus'.

${ }^{84}$ Evergates, ed., Cartulary of Homblières, 63-8 (nos. 19-22), 70-5 (nos. 24-9); 68-9 (no. 23) is questionable.

${ }^{85}$ Evergates, ed., Cartulary of Homblières, $64-5$ (no. 20).

${ }^{86}$ Evergates, ed., Cartulary of Homblières, 72 (no. 25): 'decusans suorum antecessorum negligentiam'.
} 
By the early eleventh century, monks such as Waleran were beginning to have a new, more intensive interest in the written word. ${ }^{87}$ However, there is no reason to doubt the reality of a downturn in charter production during his abbacy. This probably represents a genuine shift in documentary policy between the end of Berner's abbacy and the time of Waleran. The reasons why this should be so are of necessity speculative, but a number of possibilities spring to mind. First, even during Berner's abbacy, the number of charters preserved is substantially less after 963 than before. Archbishop Hugh of Rheims had died in or soon after 962, and with his death the 40 -year conflict over the see of Rheims came to an end. ${ }^{88}$ It is therefore possible that the decline in documentary production could be due to a general settling-down of conditions in the Rheims area. Second, and closer to home, it is possible that the reduced documentary production could reflect a slowing-down in the number of land transactions taking place. However, there is no way of demonstrating this: as the example of Castellan Lambert's gift shows, it was possible that gifts made could simply go unrecorded, and if other gifts were made in the $990 \mathrm{~s}$ or $1000 \mathrm{~s}$, we would not know of them. Third and finally, it is significant that the only surviving charters which certainly date from Alberic's reign are a donation of land from Albert the Pious and confirmation of a different gift by his son Heribert III. ${ }^{89}$ It may be that several decades of good relations with the counts of Vermandois meant that the monks of Homblières might have felt better able to rely on comital protection for their property, and subsequently less reliant on charters. Any of these suggestions individually or in combination is plausible in explaining the shift in document production.

\section{Conclusion}

The reform of Homblières seems to have come about in the context of a genuine crisis in discipline in the mid-940s. However, most of the problems or potential problems facing Homblières arose because of its size and lack of a single major patron. Abbot Berner and his community seem to have attempted to alleviate their abbey's lack of a large patrimony by consolidating their land through sales and exchanges. This in turn fed into Homblières' unusually large documentary record: having been gained, the land had to be defended.

The question of how Homblières could protect itself and its property from any potential challenge was as pressing for the abbey as for any other early medieval landholder, but the seeming lack of a major patron at Homblières who could be called on to support the monastery's claim to property should it be challenged in court or otherwise, along with the potential threat presented by Albert the Pious to the abbey's autonomy, led the abbey to seek other solutions. The tenth-century documents from Homblières should be seen in this light. These charters were legal weapons against potential threats, documents in which the figures of power surrounding Homblières wrote down and therefore made permanent their approval of transactions concerning land to which they had a claim. While they had a long-term value for the community, implicit in their preservation, their composition was informed by the immediate needs of Abbot Berner's time. Homblières' tenth-century muniments illustrate how a small community could manage its landholding in a way that allowed unusual strategies of documentary production to complement other attempts to consolidate and expand its holdings.

\footnotetext{
${ }^{87}$ Frank G. Hirschmann, 'Klosterreform und Grundherrschaft: Richard von St. Vanne', in GrundherrschaftKirche - Stadt zwischen Maas und Rhein während des hohen Mittelalters, eds. Alois Haverkamp and Frank G. Hirschmann (Mainz: Von Zabern, 1997), 141-2, 153.

${ }^{88}$ Richer of Rheims, Historiarum libri III, ed. Hartmut Hoffmann. MGH SS 38 (Hannover: Hahnsche Buchhandlung, 2000), 179.

${ }^{89}$ Evergates, ed., Cartulary of Homblières, 64-7 (nos. 20-1).
} 


\section{Acknowledgements}

I would like to thank Sam Ottewill-Soulsby, who read and commented on a first draft of this article, Dr Charles West, who made a number of extremely helpful suggestions, and Professor Rosamond McKitterick, who provided much highly appreciated advice and support throughout the writing process. All infelicities in interpretation or fact remain my own.

\section{Funding}

This work was supported by the Arts and Humanities Research Council through grant [AH/K502959/1].

Fraser McNair is a student in the Faculty of History at the University of Cambridge. He is working on a doctoral thesis on 'The Emergence of Territorial Principalities between the Loire and the Scheldt, 893987'. He holds a BA and MPhil from the University of Cambridge. 